\title{
Heat Shock Protein (Hsp) Response Within RNA Viral Nervous Necrosis (VNN) that Infect of the Humpback grouper Cromileptes altivelis
}

\author{
Uun Yanuhar ${ }^{1}$, Ryan Christiawan ${ }^{1}$, M. Mahmudi ${ }^{1}$, Asus Maizar $\mathrm{SH}^{1}$, Diana Arfiati ${ }^{1}$
}

\begin{abstract}
Induction of Hsp can trigger by cellular stressors caused by viral infections. The aim of this study is to find out of the expression of Hsp70 on C.altivelis exposured by infection of VNN. The methods were to isolate fractionate the protein of C.altivelis organs both normal and infected by of VNN by SDS-Page, and to detect the expression of Hsp70 qualitatively on tissue using Immunohistochemistry (IHC) methods. The result shows the IHC test was a positive Hsp70. The infection of VNN that have immunogenic protein on tissue organ of C.altivelis had been reacted by expression of function Hsp70. It means antigen determinant from the immunogenic protein of VNN has sensitivity highly on the reaction of Hsp70. Hsp70 can induce immune cell for the maintenance of Humpback grouper tissue receptors. The conclusion was the infection of VNN of C.altivelis was related to the expression of Hsp70.
\end{abstract}

Keywords-Humpback grouper, Hsp 70, IHC, inflammation, $V N N$.

\section{INTRODUCTION}

$\mathrm{V}_{\mathrm{it}}^{\mathrm{N}}$ $\mathrm{NN}$ is a virus with a single-stranded (+) ss-RNA. It has the reverse transcriptase enzyme and serves transcription of (+) ss-RNA into ss-DNA that integrated with the chromosome to make mRNA [1]. VNN genome is bigger (RNA1) with a size of $3.1 \mathrm{~kb}$, to encode the RNA polymerase that are RNA-dependent and RNA polymerase. The segment of the smaller genome (RNA2) has a size of $1.4 \mathrm{~kb}$ that function to encode part of the viral envelope (coat protein) [2].

VNN infection often occurs in marine farmed fish such as Humpback grouper (Cromileptes altivelis), the type of fish that is most prone to VNN. This virus was able to infect various stages of fish from larvae, juvenile, fingerling to adult. Infection of the fish was started from an inflammatory response or inflammation known as viral encephalopathy, retinopathy, even myopathy [3]. Organ eye and brain in mouse grouper (Cromileptes altivelis) were the VNN attack targets. The VNN infection in fish larvae causes vacuoles. The first vacuolation response occurs in the spinal cord, the top of the swim bladder. This infection will continue in the organs of the brain and spread to the retina which resulting in

Uun Yanuhar ${ }^{1}$ is with Faculty of Fisheries and Marine Science, University of Brawijaya, East Java, Indonesia;

Ryan Christiawan ${ }^{1}$, M. Mahmudi ${ }^{1}$, Asus Maizar $\mathrm{SH}^{1}$, Diana Arfiati ${ }^{1}$ are with Faculty of Fisheries and Marine Science, University of Brawijaya, East Java, Indonesia. the weakening of the immune response in these organs [4].

VNN attack causes a necrosis beginning from the inclusion body i.e. the cells undergo changes in the cytoplasm with the formation black dots. The subsequent event is the cells undergo a cell enlargement until the formation of a vacuole in the cell cytoplasm. It is a response to antigen attacks that occurring in the cell. The cellular response against an antigen can cause tissue damage. This damage begins with an inflammatory process as a result of a reaction of the host immune cells in the body [5]. VNN (RNA viral) infection triggers the activated inflammatory cells in the body. Similarly, tissue damage suffered an injury cell as a result of an inflammatory reaction in the body. The next response of inflammatory reaction released the immune cells to make mediators or cell-mediated immunity on further immune reaction [6-7].

The inflammatory reaction can be characterized by Heat Shock Protein 70 (Hsp70). Hsp70 is a group of stress proteins with a function to maintain the physiological tissue to the conditions of both environmental and the reaction to an antigen. It provides protection to the tissue against physical or biological triggers such as high temperatures, chemicals, conditions of hypoxia, injuries and reactions of medicinal materials. It will affect the increase of Hsp70 gene expression within a tissue or host cells [8]. Hsp70 expression also triggered by cellular stress that caused by exposure and viral infections [9].

The aim of this study was to determine the expression of Hsp70 in the case of VNN infection that attacks the Humpback grouper in relation to cellular functions of Hsp.

\section{MATERIAL AND METHODS}

\section{A. Material}

Experimental studies using Humpback grouper from Indonesian territorial waters as much as 18 fishes with average size and weight of $15 \mathrm{~cm}$ and about 50 grams, respectively. The groupers were treated with VNN infection, divided into the treatment group and the control group with each group of 9 fish.

\section{B. Procedure}

\section{Fish acclimatization}

Pisciculture adaptation was needed for 12 hours. The fish feed was given after the fish look healthy and aggressive, 
twice per day, at 08.00 and 15.00 hours. The fish feed used was in the form of fresh mackerel and chopped into small pieces. Every day, supporting parameters include temperature, salinity, and $\mathrm{pH}$ was measured to maintain the environmental conditions of fish. Total acclimatization was conducted for one week, and change of water is conducted periodically to keep water circulation remained normal.

\section{Induction of VNN into the groupers}

VNN virus samples were obtained from Humpback grouper in Situbondo Brackish Water Aquaculture Centers, Indonesia and tested positive for VNN using the PCR. The grouper that positively infected by VNN in a dying condition were stored in liquid nitrogen until it is used for the next test.

VNN test was conducted on the healthy fish by oral with inserting food in the form of organ/tissue of positive VNN groupers that encapsulated in the mackerel flesh. The dose of fish food for one meal was about $5 \%$ of the weight of the fish according to Yanuhar, et al. (2012) methods [10]. A clinical test dose of VNN on the fish as much as $0.51 \mathrm{mg} / \mathrm{ml}=510 \mu \mathrm{g}$ $/ \mathrm{ml}$ per $150 \mathrm{~g}$ of fish. The feed was given until day 23 of treatment. Changes in fish behavior were observed every hour until symptoms of whirling were visible. All the fish are maintained and observed treatment from 1 to 23 days then fish collected for observing the response to the expression of Hsp70 in both cellular and genomic.

\section{Electrophoresis SDS-Page}

Hsp70 expression in fish was observed through the organs of fish targeted by VNN infection using SDS-Page according to the method Laemli (1970), by making a two-layer gel that are separating gel and stacking gel [11]. The composition of the separating gel composition was $30 \%$ acrylamide, $1.5 \mathrm{M}$ Tris- $\mathrm{HCl} \mathrm{pH} 8.8, \mathrm{dH}_{2} \mathrm{O}$, SDS (Sodium Sulfate Dodecyl) 10\%, APS (Ammonium Persulphate) 10\%, TEMED (tetra ethylene diamine). The stacking gel was Acrylamide 30\%, 1.5 M Tris$\mathrm{HCl} \mathrm{pH} 6.8, \mathrm{dH}_{2} \mathrm{O}$, SDS 10\%, APS 10\%, TEMED. Separating gel solution was poured into a solution of the gelforming plate using a pipette until the height was threequarters of plate height. Water was poured over of the gel solution slowly so as the gel surface was not bumpy and allowed to solidify for about $30 \mathrm{~min}$. Water separating gel was discarded. Stacking gel was prepared into Erlenmeyer until the separating gel was solidified. Stacking gel solution was poured immediately into the gel-forming plate using a pipette until the plate was full. The well-forming comb is inserted into the sample slowly after the stacking gel is poured. After about 30 minutes, the gel solidifies, the comb was appointed.

The protein sample was reduced by the addition of RSB (Reducing Sample Buffer) (1: 1) and heated at $100{ }^{\circ} \mathrm{C}$ for 5 min. The sample was inserted into the gel wells with each the well volume of $18 \mathrm{~mL}$. For molecular weight protein marker was used four $\mathrm{mL}$ low range marker from PRO-STAIN ${ }^{\mathrm{TM}}$.
Electrophoresis was performed by applying an electric voltage of $100 \mathrm{~V}, 400 \mathrm{~mA}$ for $100 \mathrm{~min}$. Gel removed from the chamber; the staining was conducting using in a staining solution (coomassie blue) for $30 \mathrm{~min}$., while shaken. Staining process was stopped using the destaining solution. Furthermore, it was conducted the calculation of molecular weight of protein.

\section{Hsp70 expression using the Western blot}

Western Blot method to show the Hsp70 expression was referred to the method of Towbin [12]. Gel targets resulted from protein running was transferred to nitrocellulose paper using a semi-dry apparatus. After that, gel was stained using a dye poncho $2 \%$ (TSA up to $3 \%$ ). Nitrocellulose membrane paper was cut into the lane well and such membrane was blocked using TBE (g albumin $3 \%$ in TBE $\mathrm{pH} 7.4$ plus $1 \%$ Bovine serum albumin (BSA)) and shaken for 2 hours. Subsequent, results of blocking membrane was added by a secondary antibody which is anti-IgG anti VNN with concentration $1 / 1000$ in TBE $\mathrm{pH} 7.4$ and $1 \%$ BSA, and protected against the light. The membranes were incubated and shaken for 2 hours, then it was washed 2 times for 5 min. using TBE pH7,4 tween $200.05 \%$. The material used counterstain color was $\mathrm{Cip}^{2}$ tablet dissolved in $10 \mathrm{ml} \mathrm{H}_{2} \mathrm{O}$. Counterstain solution was poured on nitrocellulose paper and observed the occurrence of red color that appears the band of targets Hsp70. If it has reaction, the appearance of protein bands is quite clear, the membrane was rinsed with $\mathrm{H} 2 \mathrm{O}$, then dried with filter paper. $\mathrm{DAB}$ done shooting western blotting results

\section{Immunohistochemistry}

Humpback grouper organ tissue with VNN positive was cut and immersed in xylol for 5 min. Organ was rinsed with alcohol in a serial concentration of $90 \%, 80 \%$ and $70 \%$ for 5 min. 2 times each process. Then, tissue slide preparation was rinsed with $\mathrm{ddH}_{2} \mathrm{O}$ for 5 min., 3 times, and tissue slide preparation was stored in refrigerator 4 degrees for overnight.

Tissue preparations were washed with Phosphate Buffered Saline (PBS) $\mathrm{pH} 7.4$ for $5 \mathrm{~min}$, three times and incubated again with $3 \% \mathrm{H}_{2} \mathrm{O}_{2}$ for $10 \mathrm{~min}$. Blocking of unspecific protein was conducted by incubation in 5\% PBS or with 1-2\% BSA. Then, the tissue was incubated with the primary antibody anti-Hsp70 IgG antimouse by the concentration of 1: 1000 overnight, $40^{\circ} \mathrm{C}$. The results were washed with $\mathrm{PBS} \mathrm{pH}$ 7.4 for $5 \mathrm{~min}$, three times, followed by incubation in secondary antibody anti-IgG anti-mouse by the ratio of 1: 200 for 1 hour. Tissue preparat was rinsed again with PBS pH 7.4 for 5 min., three times and incubated in SA-HRP (Streptavidin-Horseradish Peoxidase) 1: 500 for $40 \mathrm{~min}$. Results of incubation then washed with PBS $\mathrm{pH} 7.4$ for 5 min, three times and added a DAB (3,3'-diaminobenzidine) chromogen for $20 \mathrm{~min}$. and washed with PBS $\mathrm{pH} 7.4$ for 5 min, three times. Once clean, it rinsed with $\mathrm{dH} 20$ for $5 \mathrm{~min}$, 
three times, then added a counterstain with major hematoxylin (HE), $10 \mathrm{~min}$. The final preparation step was tissue washed under running water, for $5 \mathrm{~min}$, repeated three times, and the wind dried. After the slide preparat dried and then mounting with the entellan and observed under a microscope.

\section{RESUlT AND DISCUSSION}

\section{Results}

After fractionation of protein of Humpback grouper tissue protein using SDS-Page (Fig.1), Hsp70 molecules expressed in fish treated by VNN (Fig.1c). It is known as the Hsp70 protein bands are molecules with a molecular weight of 70 $\mathrm{kDa}$.

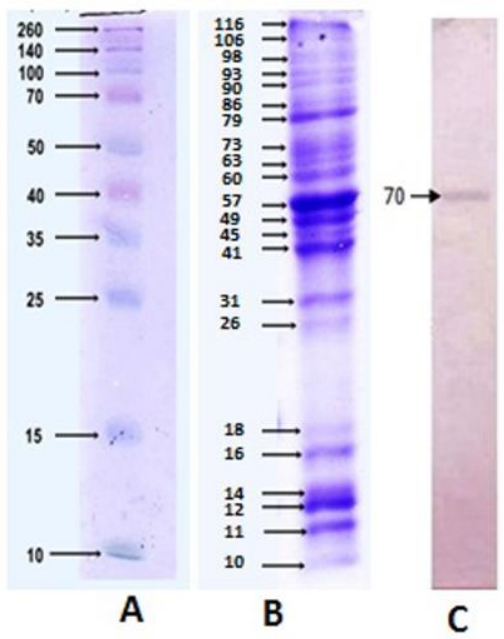

Fig. 1 Electrophoregram of Humpback grouper tissue: (A) Marker; (B) Normal Fish; (C) Infected fish by VNN

The histology of fish organ was observed using IHC as shown in Fig.2, Fig. 3, Fig. 4, Fig. 5, and Fig. 6.

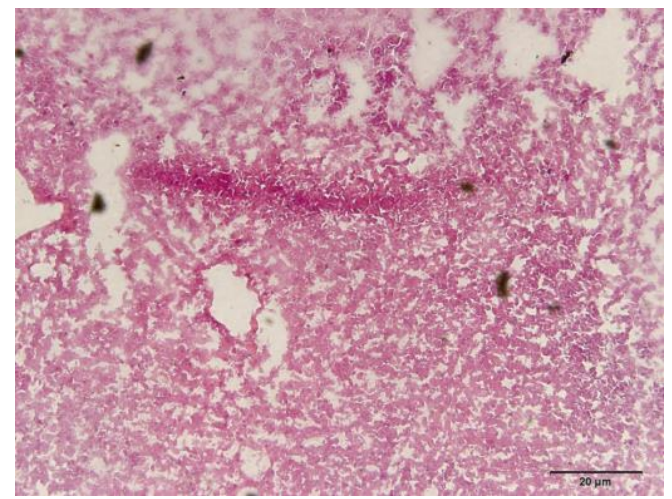

Fig. 2 Histology of normal grouper kidney with HE staining, M400X

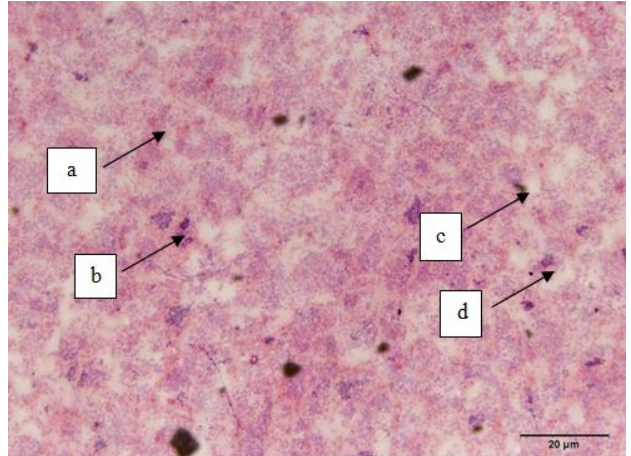

Fig. 3 Histology of grouper infected by VNN with HE staining, M400X: a. Infiltration, b. Necrosis, c hemorrhage, d. Vacuolation

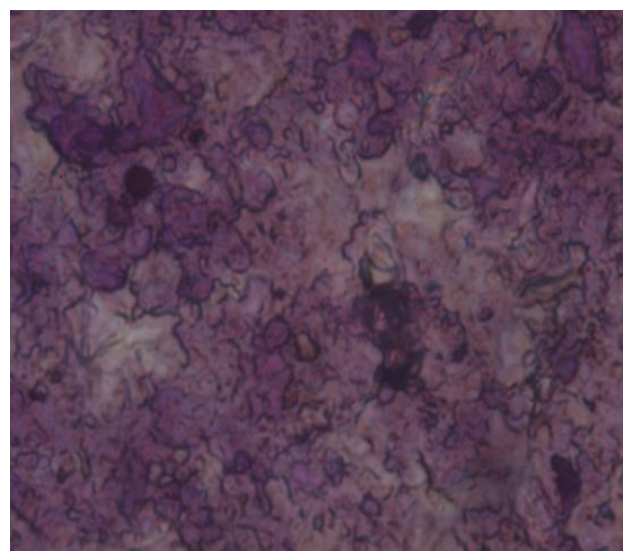

Fig. 4 Histology of normal kidney grouper with IHC expression of Hsp70 using a primary monoclonal antibody Hsp IgG anti-mouse, and secondary antibody IgG anti mouse, M 1000x

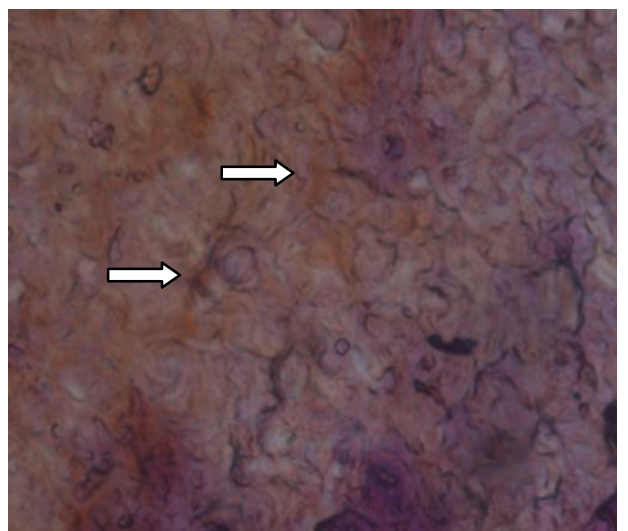

Fig. 5. Histology of kidney infected grouper by VNN with moderate expression of Hsp70 using a primary monoclonal antibody anti-Hsp IgG anti-mouse, and secondary antibody IgG anti mouse, M 1000x (Gold brown, arrow) 


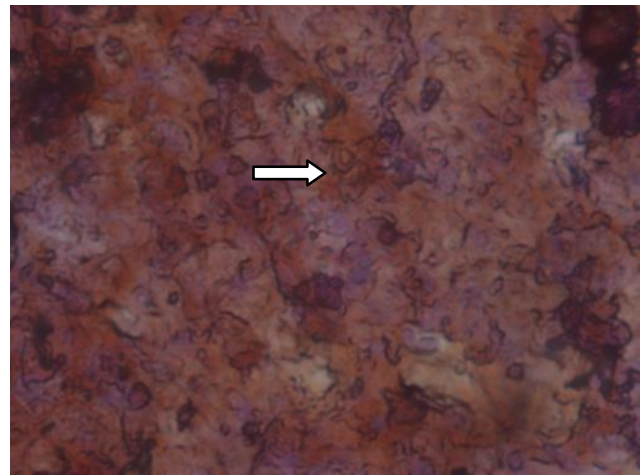

Fig. 5. Histology of kidney infected grouper by VNN with high expression of Hsp70 using a primary monoclonal antibody antiHsp IgG anti-mouse, and secondary antibody IgG anti- mouse, M 1000x, (Gold brown, arrow)

\section{Discussion}

Observations using SDS-Page to the kidney of control grouper and treatment by VNN indicate that the tissue is expressing Hsp70 molecule (molecular weight of $70 \mathrm{kDa}$ ). This response is a response to the antigen VNN. Hsp70 plays a significant role in the mechanism of immune and inflammatory responses in both the healthy/normal fish or diseased fish. Hsp expression in normal circumstances can also increase because of the presence of a stressor. Protein Hsp had important functions in the cell that is not in a state of stress, like regulate protein folds, preparation and laying of intracellular proteins. Hsp also responsible for cell protection, and ensuring cell death, according to the level of the parent cell to cell death process.

In this experiment indicated that the $\mathrm{VNN}$ had a role as a foreign antigen that causes inflammation reaction and infection in the kidney tissue of grouper. VNN infection will be triggered the active cell and immune cell differentiation to protect both tissue and cell of fish. The cells undergone a stress will cause a stress response in the form of heat shock response (Hsr). Hsr was a protective response mechanism of the cell involving gene expression and heat shock proteins (Hsp). Hsp was useful to help the organism face environmental stresses and VNN infection. Hsp in a normal tissue had a function as a molecular chaperone, a regulator, and transporter protein. Under stress conditions, Hsp keeps the aggregation of proteins, refold damaged proteins and degrade the proteins that can not be repaired. As a proinflammatory mediators, Hsp can release both the necrotic and non-necrotic substance into the extracellular environment, and produce a variety of immune and inflammatory responses, including activation of immune system effector and cytokine release. Hsp70 in the brains of experimental animals infected antigen found decreased levels of TNF- $\alpha$ and IL6 [13-14].

Hsp70 expression using IHC indicate that the IHC expression quite strongly with antibody labeling monoclonal antibody anti-Hsp IgG anti-mouse in kidney tissue induced VNN in vivo. The Hsp70 can alter the production of pro- inflammatory to immune cell like cytokine, increases antigen tolerance and increase survival of the fish that are the effects of the heat shock response (Hsr). This response is an inflammatory reaction that can be characterized by Hsp70.

Stress protein Hsp70 is a group that works to maintain the physiological tissue to a good state of environmental conditions as well as the reaction to an antigen. Hsp70 also provides protection that no tissue is damaged by infection incoming antigen. Hsp also protects against physical or biological triggers such as high temperatures, chemicals, conditions of hypoxia, infection by $\mathrm{VNN}$, injuries and reactions of medicinal materials. These will affect the increase of Hsp70 gene expression within a network or host cells [8].

The expression in increasing Hsp70 was induced by cellular stress, mainly caused by exposure and viral infections [15]. The inflammation could be indicated by pain, skin bruising, and fever reactions. These reactions occurred in a cell due to changes in blood vessels in the area of infection by antigen. The appearance of Hsp expressed caused by VNN infection in the kidney tissue of grouper as a preventive manner in this study was show that there was an inflammatory response effect that has function to inhibit the VNN virus so that the virus does not more proliferate [16].

\section{CONCLUSION}

The results of this study were reinforce the previous theory that the infection of the virus antigen RNA VNN is one trigger response to an inflammatory reaction in the tissue of fish. The response indicated by the expression of Hsp70 both quantitatively and qualitatively. Response Hsp70 was strengthened with strong conditions VNN infection with conditions such as hemorrhage tissue, tissue vacuoles, inclusion body, and necrotic. Recommendation for further study is to determine the function of Hsp70 that plays a role in the mechanism of the immune system in genomics.

\section{ACKNOWLEDGMENT}

Thanks for the Rector University of Brawijaya for grant of this publication and the State Ministry of Research, Technology and Higher Education Republic of Indonesia for research grant 2015.

\section{REFERENCES}

[1] Anthony Strelkauskas, Jennifer Strelkauskas, Danielle MoszykStrelkauskas. Microbiology: A Clinical Approach. New York: Garland Science, Taylors and Franchis Group, LLC. 2010.

[2] Nishizawa, T., K. Mori, M. Furuhashi, T. Nakai, I. Furusawa and K. MurogaComparison of the Coat Protein Genes of Five Fish Nodaviruses, the Causative Agents of Viral Nervous Necrosis in Marine Fish. Journal of General Virology vol 76, 1995, pp. 1563-1569. http://dx.doi.org/10.1099/0022-1317-76-7-1563

[3] Husgard, Susanna ; Grotmol, Sindre ; Hjeltnes, Brit K. ; Rødseth, Odd Magne ; Biering, Eirik. Immune response to a recombinant capsid protein of striped jack nervous necrosis virus (SJNNV) in turbot Scophthalmus maximus and Atlantic halibut Hippoglossus hippoglossus, and evaluation 
of a vaccine against SJNNV. Diseases of Aquatic Organisms Vol.45,

2001, pp. 33-44,

http://dx.doi.org/10.3354/dao045033

[4] Nguyen HD, Nakai T, Muroga K Progression of striped jack nervous necrosis virus (SJNNV) infection in naturally and experimentally infected striped jack Pseudocaranx dentex larvae. Dis Aquat Org Vol. 24, 1996, pp.99-105

http://dx.doi.org/10.3354/dao024099

[5] Dale, M.M., Foreman, J.C., and Fan, T.D., Textbook of Immunopharmacology, third edition, Oxford: Blackwell Scientific Publication, 1994, pp.21-34,

[6] Abbas, A. K. and A. H. Lichtman. Cellular and Molecular Immunology, fifth edition, updated edition. Pennsylvania: Elsevier saunders, 2005.

[7] Terr. Inflammation, in Stities, D.P., Terr, A.I., dan Parslow, T.G., Basic \& Clinical Immunology, eight edition, Connecticut: Appleton \& Lange, 1994, pp. 137-150

[8] Kang Y, Taldone T, Rodina A, Patel PD, Chiosis G. 2012. Heat shock protein binding compounds, compositions, and methods for making and using same. EP2467142 A2. U.S. patent. Jun 2012

[9] Asea, A. Mechanisms of Hsp72 release; J. Biosci. Vol. 32, 2007. Pp.579584. http://dx.doi.org/10.1007/s12038-007-0057-5

[10] Yanuhar, U. Gusman E., and Arfiati, D.,. The Exposure Immunogenic Protein of Viral Nervous Necrosis on Humpback Grouper That Influences to Proliferation and Expression of Immune Cells (Interferon $\gamma$ and NFKb Cell). Advances in Environmental Biology, Vol. 6(1) 2012. Pp. 388-396.

[11] Laemmli. Cleavage of structural proteins during the assembly of the head of bacteriophage T4. Nature. 1970, 15;227(5259):680-5

[12] Towbin; Staehelin, T and Gordon, J. Electrophoretic transfer of proteins from polyacrylamide gels to nitrocellulose sheets: procedure and some applications. PNAS Vol. 76 (9), 1979. Pp. 4350-4354. http://dx.doi.org/10.1073/pnas.76.9.4350

[13] Dokladny, K, Rebecca Lobb, Walker Wharton, Thomas Y. Ma, and Pope L. Moseley. LPS-induced cytokine levels are repressed by elevated expression of Hsp70 in rats: possible role of NF-kB. Cell Stress Chaperones. 15(2): 2010 Mar; pp. 153-163 http://dx.doi.org/10.1007/s12192-009-0129-6

[14] Yanuhar, U. Effects of Pigment-Protein Fraction from Nannocloropsis on TNF $\alpha$ and IL-6 which Act as an Anti-Inflammatory Viral Nervous Necrosis (VNN) Infection. Procedia Chemistry Vol. 14, 2015. Pp. 437 443 http://dx.doi.org/10.1016/j.proche.2015.03.059

[15] R J Roberts, C Agius, C Saliba, P Bossier3 and Y Y Sung. Heat shock proteins (chaperones) in fish and shellfish and their potential role in relation to fish health: a review. Journal of Fish Diseases 33 (10), 2010. Pp. 789-801

http://dx.doi.org/10.1111/j.1365-2761.2010.01183.x

[16] Janeway, C.A., Jr., Medzhitov, R., Innate immune recognition. Annual review of immunology Vol. 20, 2002, pp. 197-216.

http://dx.doi.org/10.1146/annurev.immunol.20.083001.084359 